\title{
Safety of etanercept in elderly subjects with rheumatoid arthritis
}

\author{
This article was published in the following Dove Press journal: \\ Biologics:Targets \& Therapy \\ 21 December 2009 \\ Number of times this article has been viewed
}

\section{Alfredomaria Lurati \\ Mariagrazia Marrazza \\ Katia Angela \\ Magda Scarpellini}

Fornaroli Hospital, Rheumatology Unit, Magenta, Italy
Correspondence: Alfredomaria Lurati Fornaroli Hospital, Rheumatology Unit, Magenta, Italy 20013

Tel +39029796 3833

Fax +39029796 3409

Email alfredomaria.lurati@email.it
Objective: To report side effects seen in a clinical cohort of patients aged $>65$ years with rheumatoid arthritis (RA) treated with the tumor necrosis factor- $\alpha$ TNF- $\alpha$ blocker etanercept and to compare the side effects rate with patients aged $\leq 65$ years.

Methods: All patients with RA that started etanercept and who were referred to our rheumatology unit from November 2005 to March 2009 were included in this study and prospectively followed to collect side effects related to therapy.

Results: One hundred three patients were enrolled: 41 ( 37 females, 4 males) aged $>65$ years and 62 ( 40 females, 22 males) aged $<65$ years. In the patients aged $>65$ years, the safety profile (defined as rate of side effects) of etanercept was similar to that in patients aged $\leq 65$ years $(P>0.05)$ and the survival curves between the groups were similar $(P>0.05)$.

Conclusions: In our three-year experience, the anti-TNF $\alpha$ agent etanercept has been well tolerated and safe in elderly patients. The risk of side effects in these patients was no greater than in subjects aged $\leq 65$ years. However, such inhibitors are associated with various and numerous side effects and elderly patients with RA should be carefully monitored to limit the risk of side effects during anti-TNF $\alpha$ therapy as much as possible.

Keywords: anti-TNF therapy, rheumatoid arthritis, elderly

\section{Introduction}

Rheumatoid arthritis (RA) is an erosive disease that predominantly involves the synovial tissue of joints and is characterized by variable disease onset and clinical course, potentially resulting in structural joint destruction and subsequent permanent disability. ${ }^{1}$

Epidemiological studies have shown that RA is most prevalent in those who are aged 65 years or older. ${ }^{2,3}$ The disease is commonly diagnosed between the ages of 30 and 50 years, but up to $33 \%$ of subjects may be diagnosed after the age of 60 years. Despite the high prevalence of RA in the elderly, and the likelihood that older patients have adverse reactions to medications as a result of age-related changes in drug metabolism and the presence of comorbid illnesses requiring concomitant medications, patients older than 65 years tend to be inadequately represented in RA clinical trials. ${ }^{5,6}$ Also, the tolerability of and response to therapy in these patients as a group has not been studied in detail. In one retrospective analysis of diseasemodifying antirheumatic drugs (DMARDs) including gold, D-penicillamine, azathioprine, and methotrexate (MTX), a substantially higher withdrawal rate due to toxicity was observed in patients older than 65 years compared to those younger than 65 years. ${ }^{5}$ submit your manuscript | www.dovepress.com

Dovepress
Biologics:Targets \& Therapy 20 I0:4 I-4

(C) 2010 Lurati et al, publisher and licensee Dove Medical Press Ltd. This is an Open Access article which permits unrestricted noncommercial use, provided the original work is properly cited. 
Etanercept is a recombinant human fusion protein that inhibits the activity of tumor necrosis factor (TNF) and lymphotoxin- $\alpha$. In clinical trials of RA, etanercept alone or in combination with MTX was well tolerated and produced significant sustained improvement in disease activity in patients with long-standing RA who failed multiple DMARDs and in patients with early aggressive disease who never received MTX..$^{6-10}$ Etanercept is effective in inhibiting radiographic progression in patients with RA; $72 \%$ of patients with early aggressive RA who received $25 \mathrm{mg}$ etanercept monotherapy had no new radiographic erosions during one year of treatment. ${ }^{10}$ In these clinical trials, the response to etanercept therapy in elderly patients was not described in detail.

The aim of our study was to assess whether the use of etanercept is associated with a different rate of adverse events in elderly versus younger RA subjects and whether the drug survival curves are different in the two groups.

\section{Materials and methods}

Subjects with RA (American College of Rheumatology criteria $^{11}$ ) that started etanercept from November 2005 to March 2009 and referring to our rheumatology unit were included in this study and prospectively followed. The etanercept dose was $50 \mathrm{mg}$ subcutaneously once a week. Nonsteroidal anti-inflammatory drugs (NSAIDs) and corticosteroids, if needed, MTX, or other previous DMARDs, if tolerated, were continued. A complete physical examination, standard laboratory tests, were assessed at baseline and either every two months thereafter. At the screening visit a chest X-ray, an electrocardiogram (EKG), a tuberculin skin test were performed and a complete hematic biometry analysis (complete blood count, C-reactive protein, erythrocyte sedimentation rate, creatinine, prostate-specific antigen total and free, aspartate aminotransferase and alanine aminotransferase, antinuclear antibodies, urinalysis). Patients aged $>65$ years also received an abdominal ecography, a mammography, three serial stool blood tests, and serum electrophoresis. A previous malignancy, history of cardiac failure with New York Heart Association (NYHA) class $\geq 3$, or clinical findings suspect for malignancies at the study screening were used as exclusion criteria. Safety profile points included incidence rates of all side effects (SEs) defined as: adverse events (AE, with a temporary therapy suspension), serious AE (SAE, defined as an AE that required the definitive discontinuation of the therapy and hospitalization, malignancies, and deaths), infectious diseases (IAE, with temporary or definitive therapy suspension associated with intravenous antibiotic treatment).

\section{Statistical analysis}

Pairwise comparisons were based on the Wilcoxon matched pairs signed-ranks test. The safety profile in the two groups was estimated by survival analysis, taking any AE as the event of interest using the Kaplan-Meier method. Comparisons between the resultant curves were made by log rank test. All values of $<0.05$ were considered to indicate statistical significance (two-tailed test).

\section{Results}

One hundred three caucasian patients out of 254 were eligible: 41 (37 females, 4 males) aged $>65$ years and 62 (40 females, 22 males) aged $<65$ years. Mean disease onset age was $57.4 \pm 1.7$ years in younger and $60.4 \pm 3.2$ years in older patients $(P>0.05)$. Mean age at beginning of TNF blocker was $57.8 \pm 6.9$ years in younger and $68.2 \pm 3.2$ years in older patients $(P<0.05)$. The duration of the anti-TNF treatment was $29.4 \pm 11.2$ and $27.9 \pm 3.3$ months, respectively $(P>0.05)$. In the whole population, 35 SEs $(33.98 \%$ of cases) that led to temporary/permanent withdrawal were observed (9 AEs, 20 IAEs, 6 SAEs). The rate of patients presenting SEs was $41.4 \%$ of patients aged $>65$ years versus $30.6 \%$ of patients aged $\leq 65$ years $(P=0.318$; Table 1). The survival curves of these two groups were no significantly different (Mantel-Cox log rank test, $P=0.267$; Figure 1).

Table I Number of adverse events in the groups

\begin{tabular}{lll}
\hline & $\begin{array}{l}\leq 65 \text { years old } \\
\text { patients \#62 }\end{array}$ & $\begin{array}{l}>65 \\
\text { patients \#4 I }\end{array}$ \\
\hline \# Adverse events (AEs) & 2 & 4 \\
Fever & $\mathrm{I}$ & 0 \\
Local reaction & 2 & $\mathrm{I}$ \\
Flu & & \\
\# Infectious diseases (IAE) & 3 & 2 \\
Lower Urinary tract infections & 3 & 5 \\
Upper Respiratory tract infection & 3 & 0 \\
Tonsillitis & $\mathrm{I}$ & 0 \\
Discitis & $\mathrm{I}$ & $\mathrm{I}$ \\
Mycotic infection & $\mathrm{I}$ & 0 \\
Herpes virus infection & 3 & $\mathrm{I}$ \\
Serious adverse events (SAEs) & & $\mathrm{I}$ \\
Squamocellular carcinoma & 0 & $\mathrm{I}$ \\
MGUS & 2 & $\mathrm{I}$ \\
Cardiac failure & 0 & $\mathbf{1 7}$ \\
Myocardial infarction & 0 & $\mathbf{1 9}$ \\
Total AEs & &
\end{tabular}




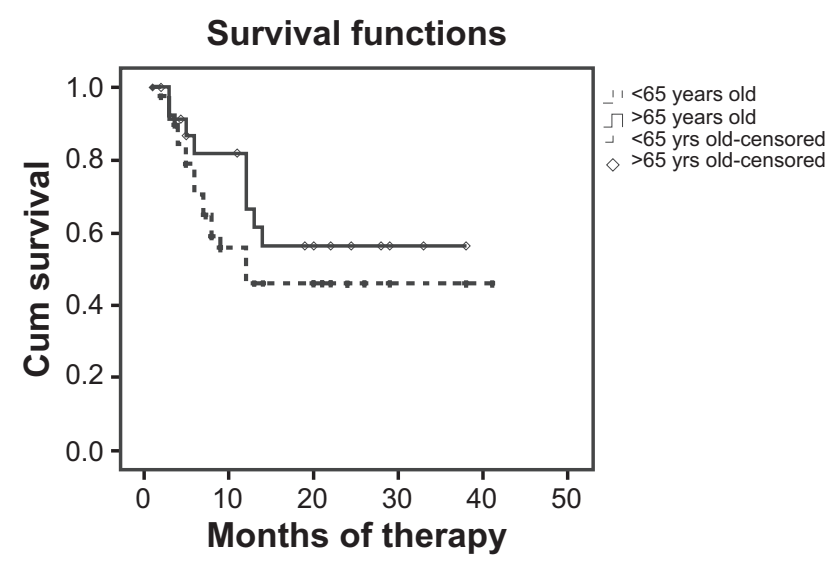

Figure I Survival curves for older and younger patients $(P>0.05)$.

\section{Discussion}

Rheumatoid arthritis is a chronic illness characterized by inflammation of the synovial tissue in joints, which can lead to joint destruction. RA affects around $0.5 \%-1 \%$ of the population, three times as many women as men, and has a peak age of onset between the ages of 40 and 70 years. The prevalence of the disease at the age of 65 years is six times the prevalence at the age of 25 years. RA is a major cause of disability and institutionalization in an aging population. ${ }^{12}$ The joint pain and swelling that are characteristic of RA often impairs mobility and the performance of activities of daily living, resulting in difficulties in self-care, diminished independence, and reduced involvement in family, work, and social roles. ${ }^{13,14}$ The influence on functional status is especially critical in older patients with RA, who also tend to have a higher frequency of acute onset and weight loss at presentation and are more likely than younger patients to have large joint involvement. ${ }^{15}$ Some studies have suggested that RA is more aggressive in the elderly, is associated with more radiographic damage, and may result in more rapid functional decline than in younger patients. ${ }^{16}$

Special issues confound the choice of therapy for elderly patients. In general, older patients are more likely to have concomitant illness including malignancies and cardiovascular disease. Additionally, they are more susceptible to serious infections and mortality from infections. Medication compliance, drug interactions, and decreased tolerability complicate the management of older patients. The older RA patient is likely to require multiple medications and have difficulties with drug compliance, and may be prone to commit dosage errors. Physiological factors in the elderly may modify pharmacokinetics, tissue responsiveness, and homeostatic mechanisms. ${ }^{17-19}$ These factors may contribute to differences in toxicity and efficacy among different age groups in patients with RA. We observed no consistent differences in the rates or types of adverse events between the age groups in this study, which suggests that treatment with etanercept does not increase the risk of these events in the elderly population beyond the increases inherent with advanced age and comorbidities.

\section{Disclosures}

The authors report no conflicts of interest in this work.

\section{References}

1. Hochberg MC. Predicting the prognosis of patients with rheumatoid arthritis: is there a crystal ball? J Rheumatol. 1993;20:1265-1267.

2. Mitchell D. Epidemiology. In: Utsinger PD, Zvaifler NJ, Erlich GE, editors. Rheumatoid Arthritis: Etiology, diagnosis, management. Philadelphia, PA: Lippincott; 1985. p. 1333-1373.

3. Robinson H. Multidisciplinary ambulatory care for the elderly arthritis patient. In: Moskowitz RW, Haug MR, editors. Arthritis and the Elderly. New York, NY: Springer Publishing; 1986. p. 146-149.

4. Fleischmann RM, Baumgartner SW, Tindall EA, et al. Response to etanercept (Enbrel) in elderly patients with rheumatoid arthritis: a retrospective analysis of clinical trial results. $J$ Rheumatol. 2003;30: 691-696.

5. Dahl SL, Samuelson CO, Williams HJ, Ward JR, Karg M. Second-line antirheumatic drugs in the elderly with rheumatoid arthritis: a post hoc analysis of three controlled trials. Pharmacotherapy. 1990;10: 79-84.

6. van Schaardenburg D, Breedveld FC. Elderly-onset rheumatoid arthritis. Semin Arthritis Rheum. 1994;23:367-378.

7. Moreland LW, Baumgartner SW, Schiff MH, et al. Treatment of rheumatoid arthritis with a recombinant human tumor necrosis factor receptor (p75)-Fc fusion protein. N Engl J Med. 1997;337:141-147.

8. Weinblatt ME, Kremer JM, Bankhurst AD, et al. A trial of etanercept, a recombinant tumor necrosis factor receptor:Fc fusion protein, in patients with rheumatoid arthritis receiving methotrexate. $N$ Engl J Med. 1999;340:253-259.

9. Moreland LW, Schiff MH, Baumgartner SW, et al. Etanercept therapy in rheumatoid arthritis. A randomized, controlled trial. Ann Intern Med. 1999;130:478-486.

10. Bathon JM, Martin RW, Fleischmann RM, et al. A comparison of etanercept and methotrexate in patients with early rheumatoid arthritis. N Engl J Med. 2000;343:1586-1593.

11. Arnett FC, Edworthy SM, Bloch DA, McShane DJ, Fries JF, Cooper NS. The American Rheumatism Association 1987 revised criteria for the classification of rheumatoid arthritis. Arthritis Rheum. 1988;31: $315-324$.

12. US Senate Special Committee on Aging, the American Association of Retired Persons, the Federal Council on the Aging, the US Administration on Aging. Aging America: Trends and projections. Washington, DC: US Government Publication; 1991.

13. Cohen F, Reese L, Kaplan G, Riggio R. Coping with the stress of arthritis. In: Moskowitz RV, Haug MR, editors. Arthritis in the Elderly. London, UK: Saunders; 1986. p. 47-55.

14. Downe-Wamboldt BL, Melanson PM. Emotions, coping, and psychological well-being in elderly people with arthritis. West J Nurs Res. 1995;17:250-265.

15. van Schaardenburg D, Breedveld FC. Elderly-onset rheumatoid arthritis. Semin Arthritis Rheum. 1994;23:367-378. 
16. van der Heijde DM, van Riel PL, van Leeuwen MA, van 't Hof MA, van Rijswijk MH, van de Putte LB. Older versus younger onset rheumatoid arthritis: results at onset and after 2 years of a prospective follow-up study of early rheumatoid arthritis. J Rheumatol. 1991;18: $1285-1289$.

17. O'Callaghan JW, Brooks PM. Disease-modifying agents and immunosuppressive drugs in the elderly. Clin Rheum Dis. 1986;12:275-289.
18. Gardner G, Furst DE. Disease-modifying antirheumatic drugs. Potential effects on older patients. Drugs Aging. 1995;7:420-437.

19. Fleischmann R, Iqbal I. Risk:benefit profile of etanercept in elderly patients with rheumatoid arthritis, ankylosing spondylitis, or psoriatic arthritis. Drugs Aging. 2007;24(3):239-254.

\section{Publish your work in this journal}

Biologics: Targets \& Therapy is an international, peer-reviewed journal focusing on the patho-physiological rationale for and clinical application of Biologic agents in the management of autoimmune diseases, cancers or other pathologies where a molecular target can be identified. This journal is indexed on PubMed Central, CAS,

\section{Dovepress}

EMBase, Scopus and the Elsevier Bibliographic databases. The manuscript management system is completely online and includes a very quick and fair peer-review system, which is all easy to use Visit http://www.dovepress.com/testimonials.php to read real quotes from published authors. 